\title{
AN ORBITAL HEMANGIOENDOTHELIOMA OF FETUS DETECTED BY PRENATAL ULTRASONOGRAPHY
}

\author{
Jin-Gon Bae, MD, Su-Yeon Lim, MD, Jeong-Ho Rhee, MD, Jong-In Kim, MD, Joon-Cheol Park, MD
}

Department of Obstetrics and Gynecology, Keimyung University School of Medicine, Daegu, Korea

\begin{abstract}
Most orbital tumors of infants include retinoblastoma, dermoid cyst (teratoma), optic nerve glioma and nevus, and hemangioendothelioma is found in rare cases. Hemangioendothelioma, the tumor of intermediate malignancy between angiosarcoma and hemangioma, is commonly recognized in soft tissue of extremities, skin, lung and liver with symptoms of ulceration and hepatomegaly in neonates and infants. However it seldom localizes in the orbit. Although there have been two case reports of orbital hemangioendothelioma in neonate and adult in Korea, there was no case report of prenatally diagnosed orbital hemangioendothelioma in fetus. We found hemangioma-like orbital tumor in a fetus at 36 weeks of gestation by prenatal ultrasonography and confirmed hemangioendothelioma by microscopic examination after birth. This is the first case of orbital hemangioendothelioma in fetus.
\end{abstract}

Keywords: Orbit; Hemangioendothelioma; Ultrasonography, prenatal

임신 제2삼분기와 제3삼분기 중 태아의 얼굴기형은 다른 기관에 기 형이 존재함을 암시하는 것일 수도 있기 때문에 이 기간 중 산전초음파 검사에서는 태아의 얼굴과 목을 관상면과 축상면 그리고 시상면을 이 용하여 각 부위를 주의 깊게 관찰하여야 한다. 태아 얼굴에서 발생하는 잘 알려진 기형들은 입술-입천장 갈림증(cleft lip and palate), 작은 턱증 (micrognathia), 큰혀증(macroglossia), 통앞뇌증(holoprosencephaly)과 관련된 안면 기형 등이 있으며 이외에 다양한 종류의 선천성 종괴들도 발생 한다. 특히 안와에는 근육, 신경, 혈관, 누선 등의 다양한 구조물들 이 포함되어 있으므로 여러 종류의 종괴들이 발생할 수 있다. 저자들은 산전초음파를 통하여 혈관종의 양상을 보이는 안와내종양을 발견하였 고, 분만 후 조직학적 검사에서 혈관내피종이 확인된 1예를 경험하였기 에 보고하는 바이다.

\section{증 례}

\section{환 자: 홍 $O$ 희, 25세}

월경 및 산과력: 초경은 13세, 주기는 28-32일 정도로 규칙적이었고, 기간은 5-7일이었으며, 양은 보통이었다. 최종 월경일은 2008년 2월 중순이었고, 분만 예정일은 2008년 12월 29일이었다.

분만력: 0-0-1-0

현병력: 임신 7주 진단 이후 정기적인 산전진찰을 받아왔으며 산전검사 에서 특기할 만한 사항은 없었으나 임신 36주경 시행한 산전초음파검 사에서 태아 머리에 거대한 종괴가 발견되어 본원 산부인과로 전원되었
다. 본원에서 시행한 초음파검사에서 좌측 안구부위에 신경모세포종 또 는 기형종으로 보이는 $6.5 \times 4.5 \mathrm{~cm}$ 크기의 종괴가 발견되었다(Figs. 1, 2). Fetal magnetic resonance imaging 소견: $9 \mathrm{~cm}$ 크기의 고형 종괴가 태아 안면부위의 전두동에 위치하고 있었으며 좌측 안구가 돌출되어 있 었다. 종괴 내부에는 다수의 혈관 구조를 확인할 수 있었으며 부분적으 로 석회화가 관찰되어 혈관종의 소견을 보였다(Fig. 3).

입원 시 진찰소견 및 경과: 입원 시 산모의 전신상태 및 활력징후는 양 호하였으며 혈액학적 검사도 정상소견을 보였다. 안구 부위의 종양으로 인한 질식분만의 어려움으로 재태기간 37주 2일에 고전적 제왕절개술 (classical cesarean section)로 분만하였고 술 후 6일째에 정상 퇴원하 였다.

Received: 2011. 5.19. Accepted: 2011. 6.24.

Corresponding author: Joon-Cheol Park, MD

Department of Obstetrics and Gynecology, Keimyung University

Dongsan Medical Center, 56 Dalseong-ro, Jung-gu,

Daegu 700-712, Korea

Tel: +82-53-250-7599 Fax: +82-53-250-7599

E-mail: jcpark@dsmc.or.kr

This is an Open Access article distributed under the terms of the Creative Commons Attribution Non-Commercial License (http://creativecommons.org/licenses/ by-nc/3.0/) which permits unrestricted non-commercial use, distribution, and reproduction in any medium, provided the original work is properly cited.

Copyright (C) 2011. Korean Society of Obstetrics and Gynecology 


\section{KOREAN JOURNAL OF OBSTETRICS \& GYNECOLOGY}

Jin-Gon Bae, et al. An orbital hemangioendothelioma of fetus detected by prenatal ultrasonography

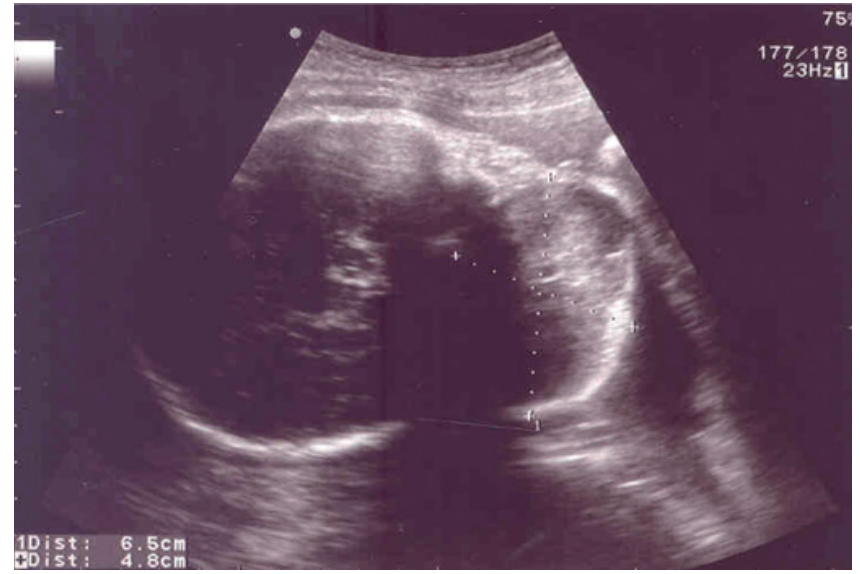

Fig. 1. At 36 weeks, ultrasonography reveals $6.5 \times 4.8 \mathrm{~cm}$ sized mass on left frontal area of fetal head.

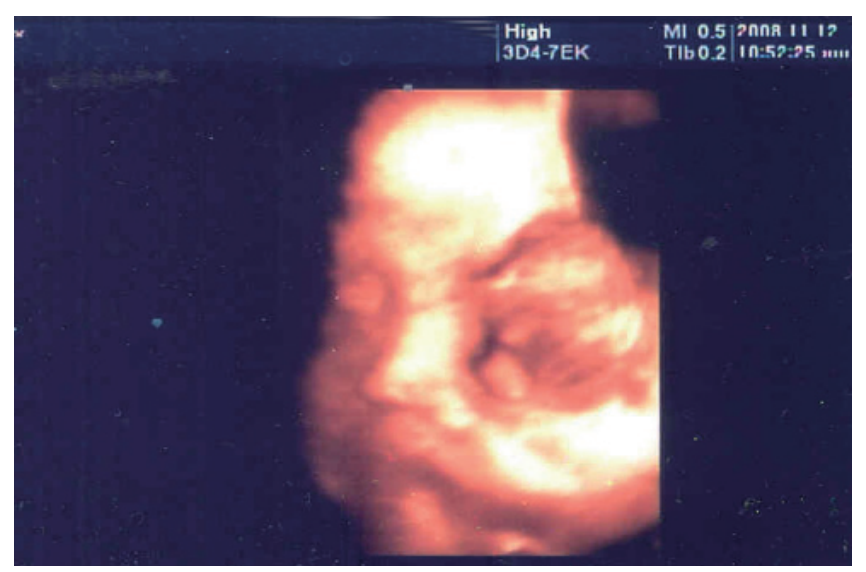

Fig. 2. 3D-ultrasonography shows heterogenous mass on left orbital area of a 36 weeks old fetus.

신생아경과: 신생아는 남아로서 출생 당시 몸무게는 $2,670 \mathrm{~g}$ 이었으 며, 아프가 점수 및 활력징후에서 특이소견을 보이지 않았다. 좌측 안 구부위와 전두동에 약 9-10 cm 크기의 종괴가 안구 전면을 덮고 있 었고, 생후 당일 시행한 MRI 검사에서 좌측 안구와 측두 아래 오목 (infratemporal fossa), 좌측 전두엽과 측두엽의 경막외 부위를 침범하는 양상을 보였다(Fig. 4). 생후 4일째에 시행한 심초음파검사에서 경도의 심방결손과 동맥관개존이 관찰되었으며, 생후 5 일째에 안면부 종괴에 세침흡입생검을 시행하여 혈관내피종(infantile hemangioendothelioma) 을 확인하였다. 신생아는 생후 15 일에 건강한 상태로 퇴원하였고, 이후 소아과와 성형외과에서 특별한 치료없이 지속적으로 관찰 중이며 현재 종괴의 크기가 감소 중이다.

\section{고 찰}

얼굴과 목에는 발생학적 기원이 다른 다양한 구조물들이 존재하므로

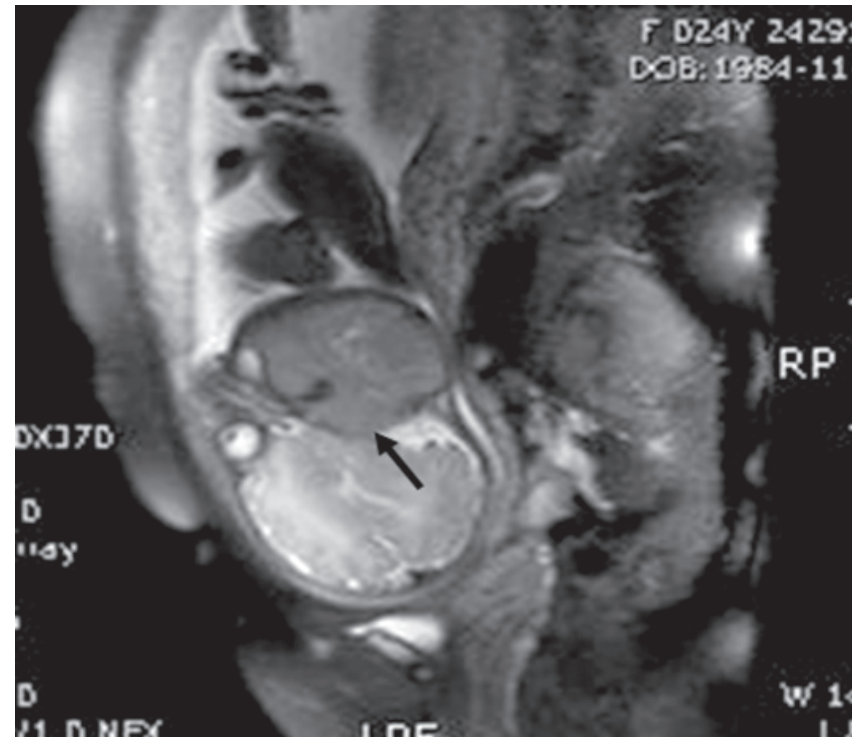

Fig. 3. Fetal magnetic resonance image shows a relatively well-definded, huge, heterog-enous, solid mass involving the left orbit, infratemporal fossa, epidural space of left frontal and temporal lobe of a fetus, measuring $82 \times 62 \times 75 \mathrm{~mm}$ (arrow). The mass is highly vascular, internal hemorrhagic and tiny calcified foci. Several large draining vessels are noted.

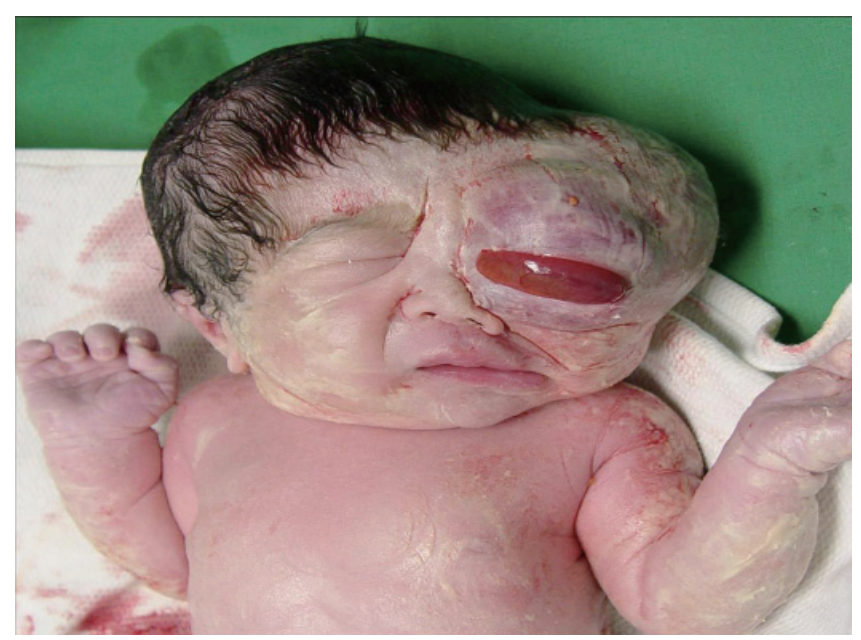

Fig. 4. After birth we defined huge orbital mass occupying left orbit and left frontotemporal area of a newborn infant.

여러 종류의 종괴들이 발생할 수 있으나 두경부라는 제한적인 부위에 발생하므로 종괴가 커짐에 따라 발생부위를 정확히 알기 어렵고 감별이 어려우므로 각 종괴의 특징들을 알고 있는 것이 진단에 도움이 된다. 일 반적으로 안면에 발생할 수 있는 종괴 중 대표적인 것으로 위턱결여증 (epignathus), 근아세포종(myoblastoma), 뇌탈출증(encepahlocele) 등이 있다[1,2]. 안와는 7 개의 뼈 조각으로 구성되는 약 $30 \mathrm{~mL}$ 의 사면추체 구 조물로서 그 안에 안구와 외안근을 형성하는 골격근, 횡문근, 신경조직, 혈관조직, 연골조직 들이 밀집해 있으며 주변으로 누선을 이루는 상피 조직과 지방조직 등 발생학적으로 다양한 조직들이 존재하므로 모든 종 


\title{
KOREAN JOURNAL OF OBSTETRICS \& GYNECOLOGY
}

\author{
KJOG Vol. 54, No. 8, 2011
}

류의 종양이 발생할 수 있다. 소아에서는 눈의 각 부위에서 성인과는 다 소 다른 종양들이 관찰되는데 안검에서는 유피낭종, 안구상에서는 모반, 안와에서는 유피낭종과 시신경교종 그리고 안내 종양으로 망막모세포 종이 주로 발견되며 망막모세포종과 유사한 모습으로 기형종을 감별해 야 한다[3].

안면에 발생하는 종양으로 뇌하수체 주머니(Rathke's cyst) 구역의 입 천장과 비인두에 발생하는 기형종인 위턱결여증(epignathus)을 들 수 있는데 $1 / 35,000$ 정도의 발생률을 보이며 초음파검사에서 일반적인 기 형종의 소견들을 보이면서 태아의 입과 코에서 돌출된다. 입안에 발생 할 수 있는 선천성 종괴로 근아세포종(myoblastoma)은 에스트로젠의 과다분비로 인해 거의 대부분 여아에서 발생하는데 입안에 발생하는 종 괴들은 양수섭취에 장애를 일으켜 양수과다증을 동반하기도 하므로 진 단에 도움이 된다[1]. 뇌탈출증도 안면이나 두개골 부위에 종괴가 있을 경우 반드시 고려해보아야 하는 비교적 흔한 선천성 기형인데 주로 두 개골의 중앙부에 위치하며 주로 낭성 소견을 보이는 경우가 많으며 두 개골의 결함이 발견된다[2]. 망막모세포종은 망막에서 발생하는 유년기 의 가장 흔한 안구 종양으로 $60 \%$ 에서는 유전적인 경향이 없이 편측성 으로 발생하지만 약 $40 \%$ 에서는 양측성 또는 다발성으로 유전적 경향 을 보인다. 산전초음파검사에서 안와에 고형종양이 발견되는 경우 의심 할 수 있으며 두개강내 또는 얼굴로 침범하기도 한다[4]. 기형종도 안와 에 발생할 경우 두개강 안으로 침범하는 경우를 보이기도 하는데 초음 파검사에서 석회화나 지방, 골조직이 혼합되어 있는 다낭성 낭포의 양 상을 보이므로 망막모세포종과 구별되며 기형종의 경우 비인두를 침범 하여 양수섭취에 장애를 일으켜 양수과다증을 동반하기도 한다[5]. 유피 낭종은 지방 성분의 액체로만 채워져 fat-fluid level을 보이는 낭포의 영 상을 관찰하여 감별할 수 있으며 모반의 경우 내부에 얇은 에코성 결절 (echogenic nodule)을 보이는 낭포가 주로 관찰되면서 많은 수의 격막 이 있어 혈관종과 유사하게 보이나 도플러 검사에서 혈류가 없는 것이 특징이다[6]. 한편 산전초음파검사에서 안구돌출, 안구 편위 등의 안과 적 이상을 일으킬 수 있는 종양이 발생할 경우 횡문근육종을 반드시 고 려해야 하는데 이는 소아에서 가장 흔한 악성종양이며 선천성의 경우 예후가 대단히 나쁘기 때문이다[7].

혈관의 종양은 양성혈관종, 국소 침습을 보이는 중간등급 종양, 악성 종양으로 구분하는데 혈관내피종(hemangioendothelioma)은 혈관종과 혈관육아종 사이의 조직학적인 소견을 보여주는 혈관종양으로 혈관종 보다는 증가된 핵이형성, 혈관의 문합성, 분열양상을 보여주며 혈관육아 종 보다는 더 초기단계의 혈관 형성 소견을 보여준다. 면역 화학적인 연 구를 통해 내피세포를 표지하는 factor VIII과 연관된 항원이나 CD31을 확인하는 것이 진단에 도움을 준다[8]. 혈관내피종은 보통 흔히 경험하 는 혈관종과는 달리 성인 시기에 주로 발생하며 주로 피부나 표재성 연 부조직에서 관찰되나 내장 특히 비장, 간, 폐에서도 발견될 수 있다. 그 러나 안와에 발생하는 경우는 매우 드물며 산전초음파검사를 통해 태아 의 간에서 종종 발견된다[9].

안와에 발생하는 혈관내피종의 가장 두드러진 증상은 안구의 돌출로 안구는 주로 내하방으로 편위되며 때로는 외측, 내측으로 편위되기도
한다. 시력장애도 오는데 이것은 종양이 직접 시신경을 침범해서 발생 할 수도 있고 안구의 압박으로 인해서 생긴 난시 때문일 수도 있다.

산전초음파검사에서 혈관내피종은 크기가 작을 경우에는 경계가 분 명한 고음영의 종물로 관찰되나 크기가 클 경우에는 혈전 형성이나 국 소적인 괴사 때문에 고음영과 저음영이 혼합된 종괴로 보인다. 일반적 인 혈관종의 경우에서처럼 동맥과 정맥의 풍부한 혈관을 관찰할 수 있 으며 동측 경동맥과 경정맥의 확장 소견도 보일 수 있다. 그러나 두경 부는 여러 구조물들이 서로 인접하여 있어 초음파 만으로는 종양의 침 범 범위를 알기 어렵고 임신 후반기에 접어들수록 두경부의 골화 때 문에 역시 초음파검사 만으로는 제한이 있어 자기공명영상(magnetic resonance imaging, MRI)을 추가적으로 사용할 수 있다. MRI는 컴퓨터 단층촬영술(computed tomography)과는 달리 전리방사선을 사용하지 않으므로 산모나 태아에게 위험하지 않은 것으로 알려져 있고 해상도 도 더 높으며 여러 방향에서의 촬영이 가능하기 때문에 종양의 특성, 범 위, 종양과 주변부와의 관계, 다른 동반 기형의 여부 등을 더욱 정확히 알 수 있어 다른 종양들과의 감별에 도움이 될 수 있다. 또한 최근 고속 영상 기술이 도입되어 산모나 태아의 움직임에 의해 발생하는 허상의 문제가 감소하고 스캔 시간이 단축되어 초음파검사 후 부가적인 검사가 필요할 때 이상적으로 이용될 수 있다[10,11].

혈관내피종은 대개 1 개월에서 6 개월 정도 지속되는 증식기를 지나면 생후 12 개월에서 18 개월에 걸쳐 자연적으로 퇴축되는 양성 질환의 성 향을 보이는 것으로 알려져 있는데 심한 안구돌출을 보이거나 안구 운 동에 심한 제약이 있어서 시력에 이상 소견을 보이는 경우는 치료의 적 응이 된다. 성인에서의 혈관종은 경계가 좋은 편이어서 외과적인 절제 가 성공적인 편이나, 영유아에서는 미만성 침윤을 보이는 경향이 있기 때문에 수술적인 제거가 어려워 부신피질호르몬을 이용한 치료가 추천 된다. 부신피질호르몬전신요법이 혈관종을 치료할 수 있다는 사실은 혈 소판 감소증과 거대혈관종을 가진 아이들에서 출혈성 경향을 치료하면 서 발견되었는데 치료 후 조직 생검에서 병리학적 소견이 혈관내피종 에서 해면혈관종의 소견으로 바뀌는 것이 관찰되었다[12,13]. 실제 생 후 신생아기에 종괴가 발견되어 부신피질호르몬 치료 후 종괴의 크기가 빠르게 감소되어 안구 운동에 호전을 보인 증례들도 보고된 바가 있으 나 본 증례에서는 특별한 치료없이 혈관내피종의 크기가 감소되고 있 는 것을 확인할 수 있었으며 산전에 안와에 혈관내피종이 발견된 예는 찾아볼 수 없었다. 이에 저자들은 간단한 문헌적 고찰과 함께 보고하는 바이다.

\section{References}

1. Gull I, Wolman I, Har-Toov J, Amster R, Schreiber L, Lessing JB, et al. Antenatal sonographic diagnosis of epignathus at 15 weeks of pregnancy. Ultrasound Obstet Gynecol 1999;13:271-3.

2. Robson CD, Barnewolt CE. MR imaging of fetal head and neck anomalies. Neuroimaging Clin N Am 2004;14:273-91. 


\section{KOREAN JOURNAL OF OBSTETRICS \& GYNECOLOGY}

Jin-Gon Bae, et al. An orbital hemangioendothelioma of fetus detected by prenatal ultrasonography

3. Roh KK, Lee JH, Youn DH. Clinical analysis in tumors of the eye and its adnexa. Korean J Ophthalmol 1988;2:27-31.

4. Salim A, Wiknjosastro GH, Danukusumo D, Barnas B, Zalud I. Fetal retinoblastoma. J Ultrasound Med 1998;17:717-20.

5. Herman TE, Vachharajani A, Siegel MJ. Massive congenital orbital teratoma. J Perinatol 2009;29:396-7.

6. Monrigal E, Gallot D, James I, Hameury F, Vanlieferinghen $P$, Guibaud L. Venous malformation of the soft tissue associated with blue rubber bleb nevus syndrome: prenatal imaging and impact on postnatal management. Ultrasound Obstet Gynecol 2009;34:730-2.

7. Sueters M, Peek AM, Ball LM, Hogendoorn PC, Scherjon SA, de Keizer RJ, et al. Prenatal detection of orbital rhabdomyosarcoma. Arch Ophthalmol 2005;123:276-9.

8. Gupta NP, Kolla SB, Panda S, Sharma MC. Epitheloid he- mangioendothelioma of urinary bladder. Indian J Urol 2008;24:253-5.

9. Kim JS, Moon SK, Yoon HS, Lee TS. A case of infantile hemangioendothelioma of the liver treated with hepatic embolization and lobectomy. Korean J Pediatr 2005;48:660-4.

10. Dreyfus M, Baldauf JJ, Dadoun K, Becmeur F, Berrut F, Ritter J. Prenatal diagnosis of hepatic hemangioma. Fetal Diagn Ther 1996;11:57-60.

11. Duncan KR. The development of magnetic resonance imaging in obstetrics. Br J Hosp Med 1996;55:178-81.

12. Roos JE, Pfiffner R, Stallmach T, Stuckmann G, Marincek B, Willi U. Infantile hemangioendothelioma. Radiographics 2003;23:1649-55.

13. Bergström K, Enoksson P, Gamstorp I, Naeser P. Haemangioendothelioma of the orbit. Ophthalmologica 1978;177:115-20.

\section{태아에서 산전초음파로 발견된 안와의 혈관내피종 1 예}

\section{계명대학교 의과대학 산부인과학교실}

배진곤, 임수연, 이정호, 김종인, 박준철

일반적으로 소아에서 안와에 발생하는 종양들로는 망막모세포종, 유피낭종(기형종), 신경교종, 모반 등이 있는데 드물게 혈관내피종이나 횡문근육종도 발생할 수 있다. 혈관내피종은 양성인 혈관종과 악성인 혈관육종 사이의 조직학적 소견을 보이는 혈관종양으로 주로 하지 의 연부조직, 피부, 폐, 간 등에서 발생하며, 신생아나 영아에서 간비대를 종종 일으킴으로써 증상이 나타나기도 한다. 안와내에 혈관내피 종이 발생하는 경우는 극히 드물며 국내에서는 신생아와 성인에서 2예가 보고된 바 있으나, 산전태아에서 발견된 예는 없다. 저자들은 재 태기간 36주의 초산모에서 산전초음파를 통하여 혈관종의 양상을 보이는 안와내 종양을 발견하였고, 분만 후 조직학적 검사에서 혈관내 피종이 확인된 1예를 경험하였기에 보고하는 바이다.

중심단어: 안와, 혈관내피종, 산전진단, 초음파검사 